\title{
owIVERSITT OF CALIFORNI
}

\author{
Radiation Laboratory \\ Contract No. W-7405-eng-48
}

TIXATION OF CAIBON DIOXIDE BT BARUEI ROOTS

$$
\text { L. W. Poel }
$$

November 30,1951 
FIXITION OF CAIBOA DIOXIDE BY BARLET ROOTS*

\author{
L. W. Poel ** \\ Radiation Laboratory \\ University of Celifornia \\ Berkeley, California \\ November 30,1951
}

The uptake of carbon dloxide by plant roots preparations has been demonstrated by various workers $(1,2,3,4)$. In addition to confirming the fact of fixation, I have Investigated the effect of a number of factors Involved and the compounds in which the absorbed carbin appears, usine carbon-14.

Exclsed berley roots, from seedlings one week old grown in tap water, were exposed to $\mathrm{C}^{14} \mathrm{O}_{2}$ wh1le supported in phosphate buffer at pH 5.6 in a elosed vessel, the radiocarbon being administered as NaHC $140_{3}$. Following the period of exposure, the buffer was decanted off, the roots were rinsed rapidly with distilled wnter and bolling 80 percent ethanol added. The material was ground thoroughly in a mortar and pestle and quantitative transfer of 11quid and solld metter made Into a graduated eylinder. Al1quots of $100 \lambda$ each of centrifuged extract were plated and counted using a thin-window Geiger tube, whence the radioactivity of the totel volume of extract was

(*) The work described in this paper was sponsored by the 0. S. Atomic Energy Commiseion.

(**) Carnegle Trust and Salth-Mundt Fellow, 1951, on Leave from Departaent of Botany, The University, St. Andrews, Scotland.

To be published in Nature. 
derived. Ceneentration of the eleer extraet to a volume of 1 to $2 \mathrm{ml}$. by vaourim distillation followed, from ellquote of which two-dimeneitonal ehroastograme on thatmen llo. 1 filter pajez vere prejered, using phenol-water and butanol-proplende aclii-water as solvents. Aledioauto, araphs were produced ty exposure of Eastman "llo Sereen" Inrw filn to the chromatourams.

The folloulng reeult to were obtalned:

2. Under virtually anaerobie conditione, the uptake of $c^{24}$ wae reduced to a very low value, dejending upon the arficleney of exvien cisplacedent.

2. When, after excieion, tho root material was hold in werated llows land solution fcr 24 hoire before exposure to $\mathrm{c}^{14}$ in ihosphate burfer, only apuroxdmately one fifth the aetivity wae incorporated as when tap or distiuled water was abetituted for the nutrient solution.

3. In experimonts involving varioue exposure times, $\mathrm{c}^{1 \mathrm{H}_{2}}$ uptake raplaty ceolined after $10 \mathrm{~min}$., only a slow rate of rixation ocourring between $30 \mathrm{~min}$. and $60 \mathrm{~min}$. (the lonsest period studied).

4. The prineipel, non-volatile, 805 ethanol-soluble ocepounde found to be radiouctive vere malle, al tric (or 1eocitrie) aspertic and clutemie colde, asparagine, giuterine, serine and tyrosine, with traces (in som experiments) of a-ketoglutarie ac1d, alanine and several as yot undetervined compounds. A typloal redio autograph 1s reprodueed. (Figure 1) 
Radioactivity hes also been found to be present in insoluble products, which are being investicated.

\section{Referenees}

1) Ruben, S: and Kamen, M. D., Proc,llat.dead.Se1., 26 (1940).

2) Overstreet, R., Ruben, s. and Broyer, T. C., Proe.llat.doad.So1.,
26 (1950).

3) Collub, M. C. and Vonneeland, B., J. B101. Chem., 160 (1947).

4) Vonnesland, B., Celthaml, J. and Collub, M. C., J. Biol. Chem.,
17 (1947): 


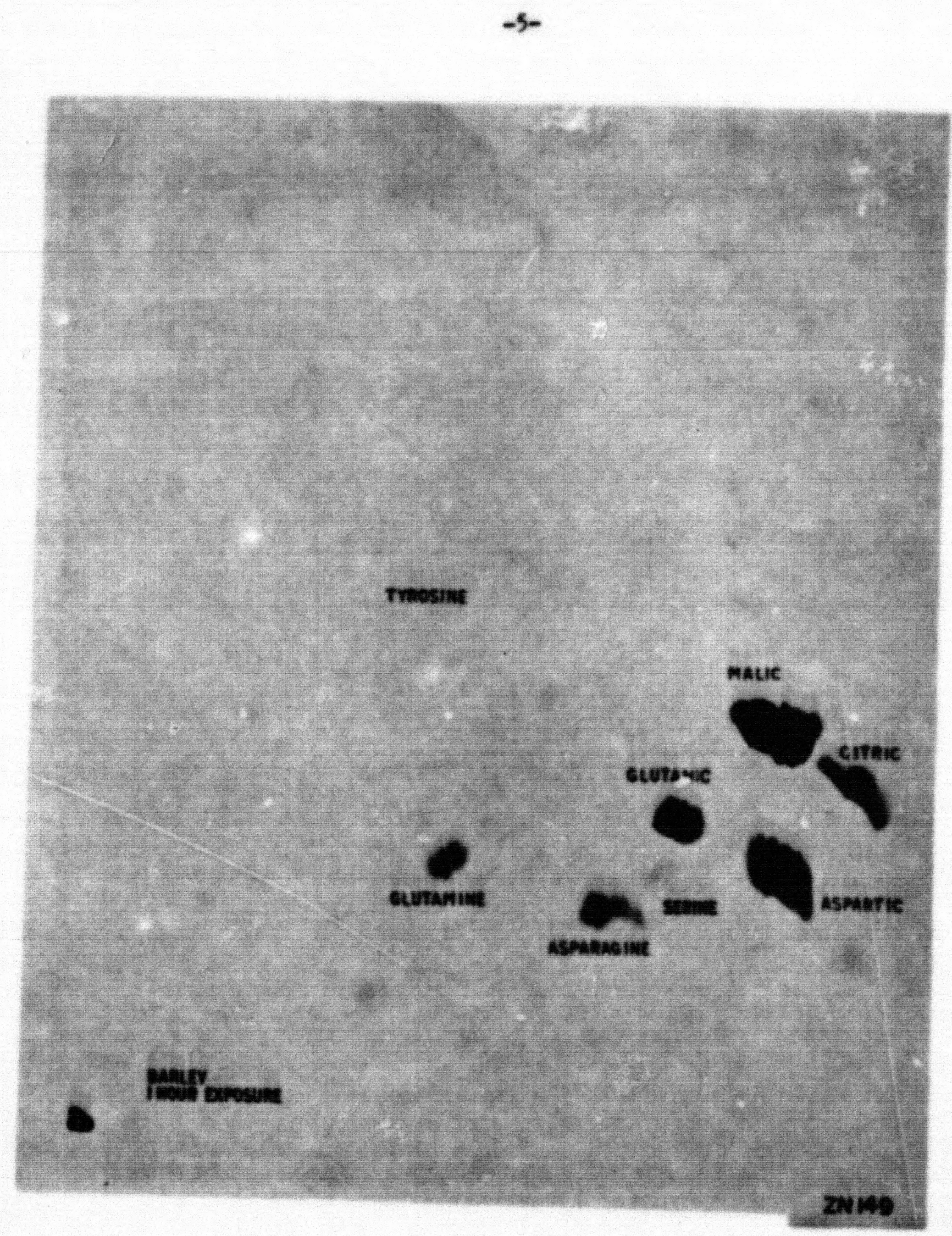

F1g. 1. Ficdiouutogruph showing redioactive, 80 percent ethanol-soluble products of $60 \mathrm{~min}$. fixatian of $\mathrm{Cl}^{14 \mathrm{O}_{2}}$ by exclsed barley roots. The chroin togram from which this rediocutogriph wcs prepered wos run horizonteliy In phenol-weter and verticelly in butanol-propionic ecid water. 


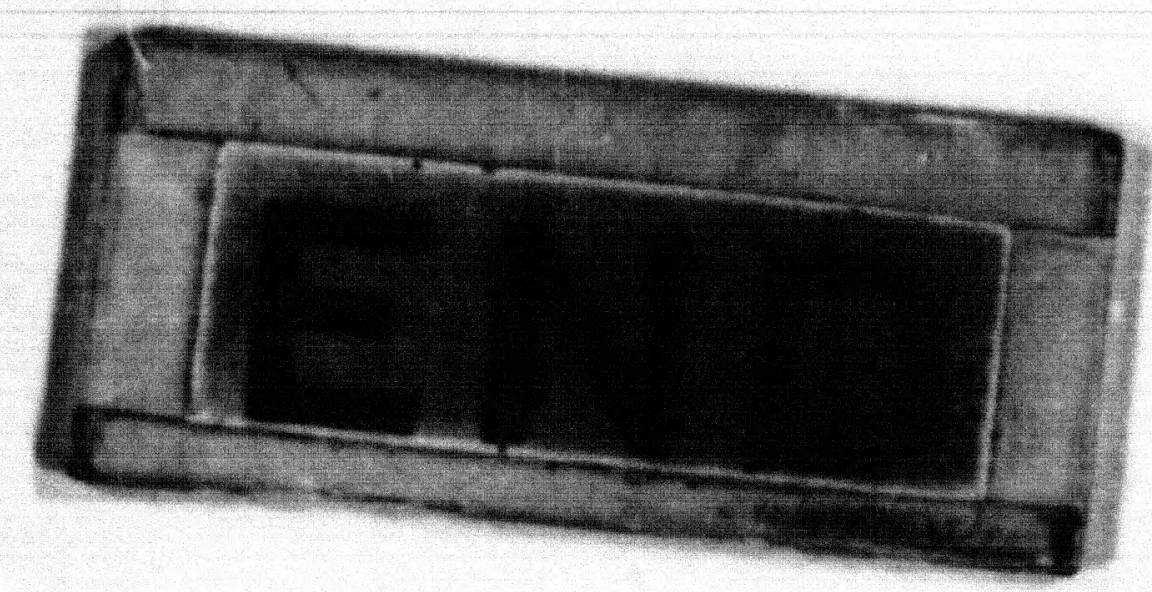

